\title{
Evaluation of Clinical, Radiological, and Demographic Characteristics of Juxtacortical Hemorrhages in Cerebral Venous Thrombosis
}

\author{
Serebral Venöz Trombozda Jukstakortikal Hemorajilerin Klinik, Radyolojik ve \\ Demografik Özelliklerinin Değerlendirilmesi
}

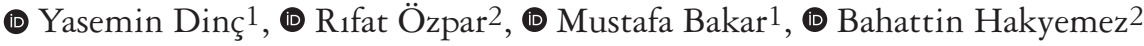 \\ 1 Uludag University Faculty of Medicine, Department of Neurology, Bursa, Turkey \\ 2Uludag University Faculty of Medicine, Department of Radiology, Bursa, Turkey
}

\begin{abstract}
Objective: Cerebral venous thrombosis (CVT) is a rare form of cerebrovascular disease. Intracranial hemorrhage may occur in $40 \%$ of the patients with CVT. The morphology of the intracranial hemorrhages ranges from small juxtacortical hemorrhages $(\mathrm{JH})$ to large parenchymal hematomas. Although it has been suggested that $\mathrm{JH}$ is a characteristic of CVT, studies examining the relationship between JH and CVT are limited. In this study, it was aimed to determine the clinical, radiological, and demographic characteristics of JH in patients with CVT.

Materials and Methods: In this study, a total of 157 patients who were followed up with the diagnosis of CVT between 2015 and 2021 were included retrospectively. Patients were categorized as, those with and without JH. Variables associated with JH were determined by comparing the demographic, clinical, and radiological characteristics, CVT etiologies and clinical outcomes of the patients.

Results: When the clinical, demographic, and radiological characteristics of the patients with and without JH were compared; female gender ( $\mathrm{p}=0.037)$, clinical initial symptom (0.003), early superior sagittal sinus (SSS) thrombosis $(\mathrm{p}<0.001)$, venous collateral scale (VCS) ( $<<0.001)$, being in the postpartum period $(\mathrm{p}=0.006)$, development of intracranial herniation $(\mathrm{p}<0.001)$, and poor clinical outcome $(\mathrm{p}<0.001)$ were significantly related with $J H$. When the significant variables were evaluated with the binary logistic regression, the most significant and independent variables were found to be SSS thrombosis ( $\mathrm{p}=0.043$ ), cortical vein thrombosis (CoVT) $(\mathrm{p}=0.010)$, and seizures after CVT $(\mathrm{p}=0.004)$. By contrast, no relationships were found between the groups in terms of VCS in binary logistic regression.

Conclusion: Diagnosis of CVT is possible with high clinical suspicion and correct interpretation of radiological imaging. JH could be detected with noncontrast cranial computed tomography, which is the first imaging modality, and may cause the clinician to suspect from SSS thrombosis and CoVT. More precise results could be obtained with the prospective multicenter studies.
\end{abstract}

Keywords: Cerebral venous thrombosis, juxtacortical hemorrhage, superior sagittal sinus thrombosis, cortical vein thrombosis

\section{$\ddot{O} \mathbf{z}$}

Amaç: Serebral venöz tromboz (SVT), serebrovasküler hastalıkların nadir görülen bir formudur. SVT tanısı alan hastaların \%40'ında intrakraniyal hemoraji meydana gelebilir. İntrakraniyal hemorajilerin morfolojisi küçük jukstakortikal hemorajilerden (JH) büyük parankimal hematomlara kadar değişir. JH'nin SVT için karakteristik olduğu öne sürülse de JH ve SVT arasındaki ilişkiyi inceleyen çalışmalar sınırlıdır. Bu çalışmada kendi popülasyonumuzda SVT tanısı alan hastalarda JH'nin klinik, radyolojik ve demografik özelliklerini belirlemek amaçland.

Gereç ve Yöntem: Bu çalışmaya 2015-2021 yılları arasında SVT tanısı ile takip edilen 157 hasta retrospektif olarak dahil edildi. Hastalar JH'si olanlar ve olmayanlar olarak kategorize edildi. Hastaların demografik, klinik, radyolojik özellikleri, SVT etiyolojileri ve klinik sonlanımları mukayese edildi, JH ile ilişkili değişkenler belirlendi.

Bulgular: JH'si olan ve olmayan hastaların klinik, radyolojik ve demografik özellikleri karşılaştırıldığında, JH'nin kadın cinsiyet (p=0,037), klinik başlangıç semptomu ( $\mathrm{p}=0,003)$, erken nörolojik kötüleşme ( $\mathrm{p}<0,001)$, superior sagittal sinüs (SSS) trombozu ( $<<0,001$ ), venöz kollateral skalası (VKS) ( $<<0,001$ ), postpartum dönemde olmak ( $\mathrm{p}=0,006)$, intrakraniyal herniasyon gelişimi $(\mathrm{p}<0,001)$ ve kötü klinik sonlanım $(\mathrm{p}<0,001)$ ile anlamlı istatistiksel ilişkisi mevcuttu. Anlamlı bulunan değişkenler binary lojistik regresyon ile değerlendirildiğinde; JH ile bağımsız olarak ilişkisi tespit edilen değişkenler SSS trombozu ( $\mathrm{p}=0,043$ ), kortikal ven trombozu (KVT) $(\mathrm{p}=0,010)$ ve SVT sonrası nöbet geçirmek ( $\mathrm{p}=0,004)$ idi, ancak VKS ile JH arasında anlamlı ilişki saptanamadı.

Address for Correspondence/Yazışma Adresi: Yasemin Dinç MD, Uludag University Faculty of Medicine, Department of Neurology, Bursa, Turkey Phone: +90 5301790512 E-mail: yaseminden87@hotmail.com ORCID: orcid.org/0000-0003-0342-5939

Received/Geliş Tarihi: 16.09.2021 Accepted/Kabul Tarihi: 20.11.2021

${ }^{\circ}$ Copyright 2021 by Turkish Neurological Society

Turkish Journal of Neurology published by Galenos Publishing House. 
Sonuç: SVT tanısı yüksek klinik şüphe ve radyolojik görüntülemenin doğru yorumlanması ile mümkündür. JH, ilk görüntüleme yöntemi olan kontrastsız kraniyal bilgisayarlı tomografi ile saptanabilir ve klinisyenin SSS trombozu ve KVT’den şüphelenmesine neden olabilir. Prospektif çok merkezli çalışmalarla daha kesin sonuçlar elde edilebilir.

Anahtar Kelimeler: Serebral venöz trombozu, jukstakortikal hemoraji, superior sagittal sinüs trombozu, kortikal ven trombozu

\section{Introduction}

Cerebral venous thrombosis (CVT) is a rare form of cerebrovascular disease (1). The annual incidence of new cases among the adults are 3-4 per million (2). The presence of various factors may play a role in the etiology. These factors are Behcet's disease, connective tissue disease, pregnancy, puerperium, oral contraceptive use, coagulopathies, lumbar puncture, intracranial infection, penetrating head trauma, malignancy, cranial tumor, dehydration, sarcoidosis, inflammatory bowel disease, parenteral infusion, and nephrotic syndrome. However, despite the numerous studies done, the cause cannot be determined in $20-25 \%$ of the patients $(3,4)$. Intracranial hemorrhage may occur in $40 \%$ of the patients with CVT (5), and it has a poor prognosis (6). The morphology of intracranial hemorrhages ranges from small, localized juxtacortical hemorrhages $(\mathrm{JH})$ to large, space-occupying hemorrhagic infarctions and subarachnoid hemorrhage (7). In recent studies on CVT and $\mathrm{JH}$, it has been determined that $\mathrm{JH}$ is a characteristic for CVT (8). Diagnosis of CVT could be difficult. Therefore, it is important to recognize the findings suggestive of CVT on cranial imaging and to determine the clinical significance of these findings. The management of the CVT focuses on timely diagnosis and treatment with anticoagulation to prevent the thrombus dissemination and recanalization (9). Although it has been suggested that $\mathrm{JH}$ is a characteristic of CVT, studies examining the relationship between $\mathrm{CVT}$ and $\mathrm{JH}$ are limited. The aim of this study was to determine the clinical, radiological, and demographic features of $\mathrm{JH}$ in patients with CVT.

\section{Materials and Methods}

This study retrospectively included 157 patients, all of whom were followed up with the diagnosis of CVT in the Department of Neurology, Uludag University, Faculty of Medicine, between 2015 and 2021. Approval for the study was obtained from the Clinical Research Ethics Committee of Uludag University Faculty of Medicine dated 26 May, 2021 and numbered 2021-6/41. As this was a retrospective study, patient consent was not required.

Inclusion criteria for the study were getting a diagnosis of CVT with contrast-enhanced cranial magnetic resonance imaging (MRI) venography, completing the necessary tests to determine the etiology of CVT after the diagnosis of CVT, and completing the regular examinations in the Neurology Outpatient Clinic of Uludag University Faculty of Medicine for one year after the diagnosis of CVT. Exclusion criteria were the patient's withdrawal from neurology outpatient follow-up and the patient's inability to undergo contrast-enhanced MRI venography, cranial MRI, and non-contrast cranial computed tomography (CT).

In our center, all medical records were recorded in the medical operating system. All patients were examined in the emergency department together with a neurologist and neurology assistant. The patients' complaints, neurological examination findings, concomitant diseases, and the drugs they used were recorded in the epicrisis. The patients were evaluated in terms of the rheumatological disease and hypercoagulability. During the follow-up of the patients in the neurology clinic, any early neurological deterioration was determined from the recorded epicrisis. Early neurological worsening was defined as a twopoint increase in the NIHSS score after the admission from the emergency department to the neurology department for further management of the patient. Epileptic seizures were excluded from these criteria (10).

The clinical outcome of the patients was determined at the third month in the neurology outpatient clinic. Modified Rankin scale scores of 0,1 , and 2 were considered as good clinical outcomes, while scores of 3, 4, 5, or 6 were considered as poor clinical outcome. All cranial CT and MRI venographies of the patients were evaluated blindly by the radiologist.

$\mathrm{JH}$ was defined as hemorrhage, when the hemorrhage is $<20$ $\mathrm{mm}$ in diameter located in the white matter just below the cortex (Figure 1) (8). Venous collateral scale (VCS) was evaluated with the contrast-enhanced cranial MRI venography in the emergency department. VCS 0 indicates a lack of venous drainage in the brain parenchyma affected by the cerebral venous sinus thrombosis, VCS 1 indicates a vein draining the affected area but not connected to an open sinus, VCS 2 indicates that a vein draining the area affected by venous sinus thrombosis is connected to an open sinus and may function as a suitable venous collateral (11). All the images were evaluated in terms of the VCS score obtained from the MRI venography, and with non-contrast cranial CT and T2W cranial MRI for the presence of hematoma and the brain injury associated with venous occlusion.

All the patients were followed up in the Neurology Outpatient Clinic of Uludag University Medical Faculty for one year, and at the end of the first year, they were questioned about whether they had any epileptic seizures during the period. Cranial CT performed in the emergency department revealed 23 patients with JH. Clinical, demographic, and radiological features of the patients with and without JH were evaluated.

\section{Statistical Analysis}

The radiological, demographic, and clinical data of the patients with and without JH were compared. Statistical analysis was performed using the IBM SPSS Statistics 25.0 package (IBM Corp., Armonk, New York, USA). Shapiro-Wilk test, a histogram, and a Q-Q plot were applied to determine the data normality. Mean and standard deviation or median $(25-75 \%$ quartiles) values were then used for the analysis of continuous variables. Frequencies and percentages were given for categorical variables. Two-sided independent samples t-test or two-sided Mann-Whitney $U$ test was used to analyze the differences between groups in terms of continuous variables. Two-Way Fisher's Exact, 


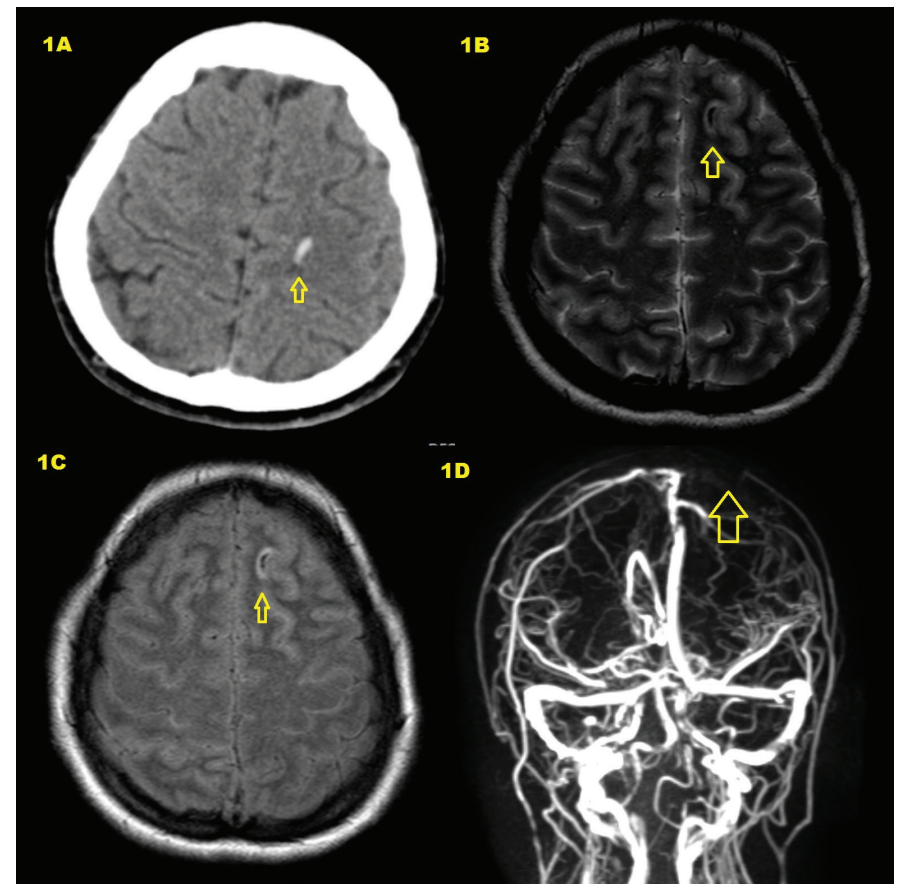

Figure 1. Juxtacortical hemorrhage secondary to isolated cortical venous thrombosis. Non-contrast CT image (1A) and T2-weighted (T2W) MRI image (1B); hyperdense on CT, T2W hypointense acute juxtacortical parenchymal hemorrhage. FLAIR MRI sequence (1C); area of hyperintense edema around the hemorrhage. MRI venography examination (1D); Isolated absence of thrombosis in the left trolard vein, superior sagittal sinus in normal appearance

CT: Computed tomography, MRI: Magnetic resonance imaging

Pearson, chi-square, and Continuity correction tests were used for (2x2) or (rxc) tables to analyze the differences between the groups in terms of categorical variables. Logistic regression analysis was performed to determine the most statistically relevant factors in the patients with CVT with JH. A p value of $<0.05$ was considered as statistically significant.

\section{Results}

A total of 157 patients, $50(31.8 \%)$ men and $107(68.2 \%)$ women were included in this study. The mean age of women was $40.99 \pm 13.97$ years, and the mean age of men was $43.60 \pm 16.30$ years. There was no statistically significant difference found between the mean ages of men and women $(p=0.293)$.

The etiologies of CVT were pregnancy and puerperium in 31 (19.7\%) patients, rheumatologic disease in 25 (15.9\%) patients, hyper-coagulopathy in $22(14 \%)$ patients, malignancy in 25 $(15.9 \%)$ patients, infection in $9(5.7 \%)$ patients, oral contraceptive use in $11(7 \%)$ patients, trauma and mechanical effects in $6(3.8 \%)$ patients, and other causes in $9(5.7 \%)$ patients. The etiology was unknown in $20(12 \%)$ patients. When the initial symptoms of the patients were evaluated, the first symptom was found to be the isolated intracranial hypertension in 108 (68.8\%) patients, epileptic seizure in $26(16.5 \%)$ patients, focal neurologic deficit in
$22(14 \%)$ patients, and encephalopathy in $1(0.6 \%)$ patient.

When the VCS of the patients were evaluated, there were 34 $(21.6 \%)$ patients with VCS 0, $31(19.7 \%)$ patients with VCS 1, and $92(58.7 \%)$ patients with VCS 2.

There were $48(30.5 \%)$ patients with an early neurological deterioration. In this study, no patients had a history of epilepsy before the diagnosis of CVT. At the end of the first year, they were questioned about whether they had seizures or not, and the information collected were recorded in the epicrisis. There were 46 patients $(29 \%)$ who had seizures in the first year. In our study, there were $35(22 \%)$ patients with poor clinical outcome. When $\mathrm{JH}$ and clinical, radiological, and demographic characteristics were evaluated, there were relationships between the $\mathrm{JH}$ and gender $(\mathrm{p}=0.037)$, initial symptom $(\mathrm{p}=0.003)$, early neurological worsening $(\mathrm{p}<0.001)$, SSS thrombosis $(\mathrm{p}<0.001)$, cortical vein thrombosis (CoVT) $(\mathrm{p}<0.001)$, being in the postpartum period $(\mathrm{p}=0.006)$, development of intracranial herniation $(\mathrm{p}<0.001)$, and the clinical outcome $(\mathrm{p}<0.001)$. However, no statistically significant result was found between the JH and age, CVT etiology, transverse sinus occlusion, sigmoid sinus occlusion, jugular sinus occlusion, inferior sagittal sinus occlusion, oral contraceptive use, pregnancy, presence of malignancy, and the presence of coagulopathy ( $\mathrm{p}>0.05)$ (Table 1$)$.

When statistically significant clinical, radiological, and demographic variables for $\mathrm{JH}$ were analyzed with the binary logistic regression, the most significant variables for JH were SSS thrombosis $[\mathrm{p}=0.043$, odds ratio $(\mathrm{OR}): 5.54]$, CoVT $(\mathrm{p}=0.010$, OR: 12.54), and seizures ( $\mathrm{p}=0.004$, OR: 16.30) (Table 2).

\section{Discussion}

In this study, the most significant variables related to $\mathrm{JH}$ were found to be SSS thrombosis and CoVT, and seizures within the first year.

Previous studies have found the evidence of a significant relationship between $\mathrm{JH}$ and SSS (8). Also, in this study, a significant relationship was found between SSS thrombosis and $\mathrm{JH}$, consistent with the literature. This may be because the SSS drains many cortical veins. The SSS is the main sinus that drains the cerebrospinal fluid. Intracranial pressure rises in SSS thrombosis, and there is an increase in pressure in the cortical and subcortical veins (12). Intracranial hemorrhage in CVT is associated with the increased venous pressure, ischemia, and then disruption of the blood-brain barrier with erythrocyte diapedesis (13). In an experimental study, it was found that intracranial hemorrhage was associated with the involvement of CoVT (14). Other studies showed that involvement of CoVT was not necessary, and occlusion of the major sinuses was sufficient $(15,16)$.

In this study, it was determined that one of the most important variables associated with $\mathrm{JH}$ was CoVT. There are two venous systems in the brain, the superficial and deep cerebral veins. The superficial venous system consists of the intracortical and subcortical veins. Connections between the superficial and deep systems could be provided via anastomotic medullary and transcerebral veins. In the venous phase of the intracranial circulation, blood is collected in the subcortical and intracortical veins, and is then transported from the pial veins to the cortical veins. Cortical vessels drain into the SSS. The subcortical vessels are divided into three parts, one of which is the curved segment. The curved subcortical vessels run parallel to the curved fibers (U-fibers) in the 
Table 1. Comparison of clinical, demographic, and radiological features of the patients with and without juxtacortical hemorrhage

\begin{tabular}{|c|c|c|c|}
\hline & $\begin{array}{l}\text { Patients with juxtacortical } \\
\text { hemorrhage }(n=23)\end{array}$ & $\begin{array}{l}\text { Patients without juxtacortical } \\
\text { hemorrhage }(n=134)\end{array}$ & $\mathrm{p}$ value \\
\hline Gender (female)* & $20(86.9 \%)$ & $87(64.9 \%)$ & 0.037 \\
\hline Age $^{* *}$ mean \pm SD & $40.09 \pm 15.359$ & $42.12 \pm 14.686$ & 0.478 \\
\hline Initial clinical symptom* & - & - & 0.003 \\
\hline Isolated intracranial hypertension & $9(39.1 \%)$ & $99(73.8 \%)$ & - \\
\hline Focal neurological deficit & $7(30.4 \%)$ & $15(11.1 \%)$ & - \\
\hline Epileptic seizure & $7(30.4 \%)$ & $19(14.1 \%)$ & - \\
\hline Encephalopathy & $0(0 \%)$ & $1(0.7 \%)$ & - \\
\hline Early neurological deterioration* & $17(73.9 \%)$ & $31(23.1 \%)$ & $<0.001$ \\
\hline Superior sagittal sinus thrombosis* & $18(78.2 \%)$ & $44(32.8 \%)$ & $<0.001$ \\
\hline Transverse sinus thrombosis* & $15(65.2 \%)$ & $100(74.6 \%)$ & 0.346 \\
\hline Sigmoid sinus thrombosis * & $12(52.1 \%)$ & $11(8.2 \%)$ & 0.305 \\
\hline Jugular vein thrombosis* & $9(39.1 \%)$ & $45(33.5 \%)$ & 0.605 \\
\hline Inferior sagittal sinus thrombosis* & $2(8.2 \%)$ & $21(15.6 \%)$ & 0.732 \\
\hline Cortical vein thrombosis* & $21(91.3 \%)$ & $24(17.9 \%)$ & $<0.001$ \\
\hline Venous collateral scale* & - & - & $<0.001$ \\
\hline VCS 0 & $16(69.5 \%)$ & $18(13.4 \%)$ & - \\
\hline VCS 1 & $4(17.3 \%)$ & $27(20.1 \%)$ & - \\
\hline VCS 2 & $3(13.0 \%)$ & $89(66.4 \%)$ & - \\
\hline \multicolumn{4}{|l|}{ Etiology of CVT } \\
\hline Being in the postpartum period* & $16(69.5 \%)$ & $11(8.2 \%)$ & 0.006 \\
\hline Using oral contraceptive* & $4(17.3 \%)$ & $8(5.9 \%)$ & 0.808 \\
\hline Pregnancy* & $0(\% 0)$ & $4(2.9 \%)$ & 0.257 \\
\hline Malignancy* & $4(17.3 \%)$ & $18(13.4 \%)$ & 0.622 \\
\hline Coagulopathies* & $10(43.4 \%)$ & $13(9.7 \%)$ & 0.223 \\
\hline Having an epileptic seizure & $20(86.9 \%)$ & $26(19.4 \%)$ & $<0.001$ \\
\hline Development of intracranial herniation* & $9(39.1 \%)$ & $8(5.9 \%)$ & $<0.001$ \\
\hline Clinical outcome* (poor clinical outcome) & $13(56.5 \%)$ & $22(16.4 \%)$ & $<0.001$ \\
\hline
\end{tabular}

white matter, following the curvature of the cortex which is like JH. It has been suggested that subcortical veins are weaker and more prone to rupture compared to the cortical veins. In patients with CVT, JH may occur when rupture occurs in subcortical veins due to the increase in pressure, and subarachnoid hemorrhage may occur when rupture occurs due to an increased pressure in the intracortical veins $(12,17,18)$. Although the relationship between VCS and parenchymal lesions has been demonstrated in many other studies, there is no study found reporting its relationship with the $\mathrm{JH}$ alone. According to the logistic regression analysis in this study, no statistically significant relationship was found between the VCS and the JH. The VCS has been defined for venous sinus thrombosis. In an isolated CoVT, the VCS is not defined. The possible reason for the lack of a statistically significant relationship between $\mathrm{JH}$ and VCS may be the close relationship between $\mathrm{JH}$ and CoVT.

As a result of this study, seizure was defined as one of the variables most associated with JH. Epileptic seizures are more common in CVT than in the arterial strokes. Epileptic seizure is also a common clinical phenomenon of CVT $(19,20,21)$. Approximately $35-40 \%$ of the patients with CVT have a history of epileptic seizures $(22,23,24)$. It may occur early or late in the disease progression process $(21,22)$. In this study, a total of 46 patients (29\%) had epileptic seizures within the first year. These epileptic seizures may adversely affect the prognosis. Seizure in the patients with CVT is a poor prognostic factor, and results 
Table 2. Evaluation of significant variables for juxtacortical hemorrhage in cerebral venous thrombosis using binary logistic regression analysis

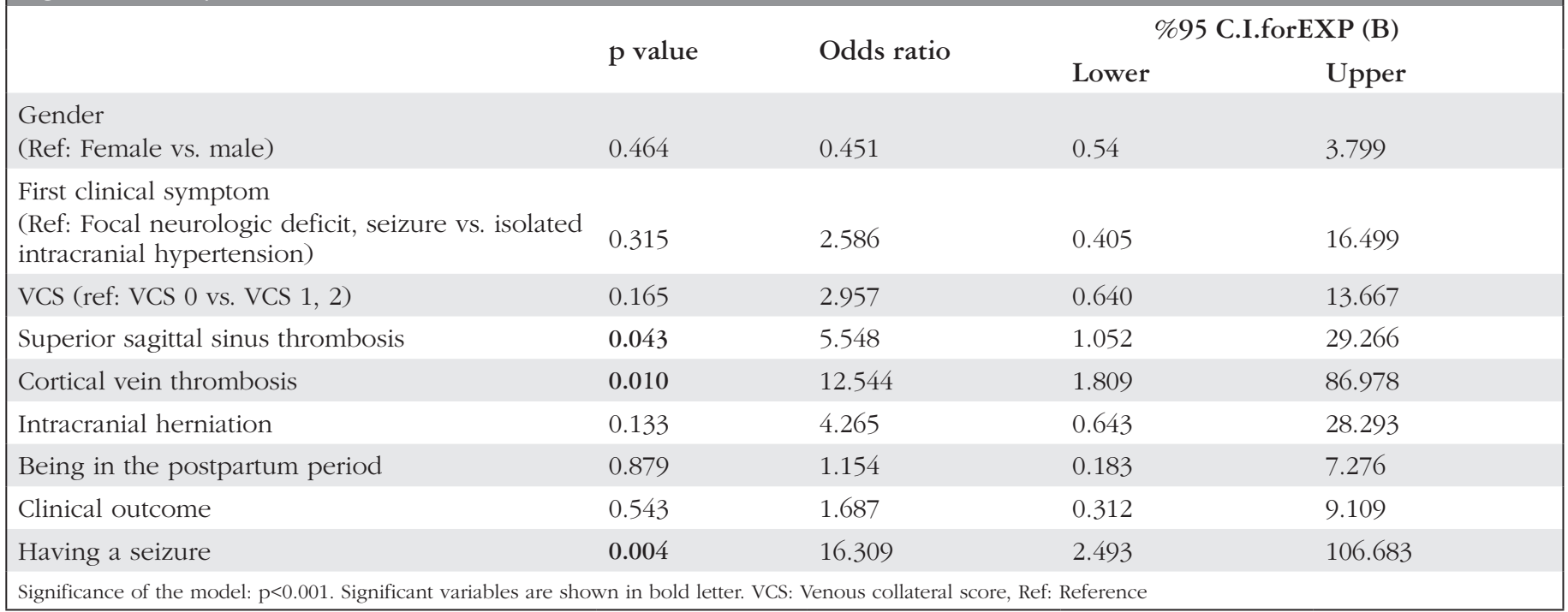

in three times higher mortality than in the patients without the epileptic seizures (22). In the largest and most recently published cohort study on CVT, risk factors for epileptic seizure were found to be SSS thrombosis, intracranial hemorrhage, and CoVT (25). The close relationship between $\mathrm{JH}$ and epileptic seizures may be due to the proximity of $\mathrm{JH}$ to the cortex, vasogenic edema, disruption of the blood-brain barrier, changes in extracellular ions, excessive release of excitatory neurotransmitters, glutamate, free radicals, and changes in the way of cells producing energy. In addition, neuronal and synaptic loss, and abnormal sprouting and permanent changes in the brain parenchyma may also trigger epileptic seizures $(26,27)$.

\section{Study Limitation}

The most important limitations of the study were that it was a single center and retrospective study, and the sample size was small. More conclusive results could potentially be achieved with the prospective and multicenter studies.

\section{Conclusion}

CVT is difficult to diagnose due to the clinical heterogeneity and various etiological factors. Diagnosis could be made with a high clinical suspicion and correct interpretation of radiological imaging. JH could be detected by a non-contrast cranial CT, which is the first imaging modality in CVT, and may cause the clinician to suspect SSS thrombosis and CoVT. More precise results could be obtained with the prospective multicenter studies.

\section{Ethics}

Ethics Committee Approval: Approval for the study was obtained from the Clinical Research Ethics Committee of Uludag University Faculty of Medicine dated 26 May, 2021 and numbered 2021-6/41.

Informed Consent: Retrospective study.
Peer-review: Externally and internally peer-reviewed.

\section{Authorship Contributions}

Surgical and Medical Practices: Y.D., R.Ö., M.B., B.H., Concept: Y.D., R.Ö., M.B., B.H., Design: Y.D., R.Ö., M.B., B.H., Data Collection or Processing: Y.D., R.Ö., Analysis or Interpretation: Y.D., R.Ö., M.B., B.H., Literature Search: Y.D., R.Ö., Writing: Y.D., R.Ö.

Conflict of Interest: No conflict of interest was declared by the authors.

Financial Disclosure: The authors declared that this study received no financial support.

\section{References}

1. Bousser MG, Crassard I. Cerebral venous thrombosis, pregnancy and oral contraceptives. Thromb Res 2012;130(Suppl 1):S19-22.

2. Stam J. Thrombosis of the cerebral veins and sinuses. N Engl J Med 2005;352:1791-1798.

3. Kimber J. Cerebral venous sinus thrombosis. QJM 2002;95:137-142.

4. Ferro JM, Canhão P, Bousser MG, et al. Cerebral vein and dural sinus thrombosis in elderly patients. Stroke 2005;36:1927-1932.

5. Ferro JM, Bousser MG, Canhão $P$, et al. European Stroke Organization guideline for the diagnosis and treatment of cerebral venous thrombosis - endorsed by the European Academy of Neurology. Eur J Neurol 2017;24:1203-1213.

6. Dinc Y, Özpar R, Hakyemez B, Bakar M. The relationship between early neurological deterioration, poor clinical outcome, and venous collateral score in cerebral venous sinus thrombosis. Neurol Sci Neurophysiol 2021;38:158165.

7. Afifi K, Bellanger G, Buyck PJ, et al. Features of intracranial haemorrhage in cerebral venous thrombosis. J Neurol 2020;267:3292- 3298.

8. Coutinho JM, van den Berg R, Zuurbier SM, et al. Small juxtacortical hemorrhages in cerebral venous thrombosis. Ann Neurol 2014;75:908-916.

9. Coutinho J, de Bruijn SF, Deveber G, Stam J. Anticoagulation for cerebral venous sinus thrombosis. Cochrane Database Syst Rev 2011;2011:CD002005. 
10. Cuadrado-Godia E. Early neurological deterioration, easy methods to detect it. Indian J Med Res 2015;141:266-268.

11. Sheth SA, Trieu H, Liebeskind DS, et al. Venous collateral drainage patterns predict clinical worsening in dural venous sinus thrombosis. J Neurointerv Surg 2018;10:171-175.

12. Okudera T, Huang YP, Fukusumi A, et al. Micro-angiographical studies of the medullary venous system of the cerebral hemisphere. Neuropathology 1999;19:93-111.

13. Röther J, Waggie K, van Bruggen N, de Crespigny AJ, Moseley ME. Experimental cerebral venous thrombosis: evaluation using magnetic resonance imaging. J Cereb Blood Flow Metab 1996;16:1353-1361.

14. Gotoh M, Ohmoto T, Kuyama H. Experimental study of venous circulatory disturbance by dural sinus occlusion. Acta Neurochir (Wien) 1993;124:120126.

15. Schaller B, Graf R, Sanada Y, et al. Hemodynamic changes after occlusion of the posterior superior sagittal sinus: an experimental PET study in cats. AJNR Am J Neuroradiol 2003;24:1876-1880.

16. Kurokawa Y, Hashi K, Okuyama T, Uede T. Regional ischemia in cerebral venous hypertension due to embolic occlusion of the superior sagittal sinus in the rat. Surg Neurol 1990;34:390-395.

17. Oppenheim C, Domigo V, Gauvrit JY, et al. Subarachnoid hemorrhage as the initial presentation of dural sinus thrombosis. AJNR Am J Neuroradiol 2005;26:614-617.

18. Qureshi AI. A classification scheme for assessing recanalization and collateral formation following cerebral venous thrombosis. J Vasc Interv Neurol 2010;3:1-2.
19. Ferro JM, Correia M, Rosas MJ, et al. Seizures in cerebral vein and dural sinus thrombosis. Cerebrovasc Dis 2003;15:78-83.

20. Ferro JM, Canhão P, Bousser MG, et al. Early seizures in cerebral vein and dural sinus thrombosis: risk factors and role of antiepileptics. Stroke 2008;39:1152-1158.

21. Masuhr F, Busch M, Amberger N, et al. Risk and predictors of early epileptic seizures in acute cerebral venous and sinus thrombosis. Eur $\mathrm{J}$ Neurol 2006;13:852-856.

22. Mehndiratta P, Koubeissi MZ. Seizures in cerebrovascular disorders: a clinical Guide. In: Koubeissi Mohamad Z, Alshekhlee Amer (eds). Chapter 8: Seizures in cerebral venous sinus thrombosis. Springer New York, 2015:95-101.

23. Ferro JM, Canhão $P$, Stam J, et al. Prognosis of cerebral vein and dural sinus thrombosis: results of the International Study on Cerebral Vein and Dural Sinus Thrombosis (ISCVT). Stroke 2004;35:664-670.

24. Ameri A, Bousser MG. Cerebral venous thrombosis. Neurol Clin 1992;10:87-111.

25. Uluduz D, Midi I, Duman T, et al. Epileptic seizures in cerebral venous sinus thrombosis: subgroup analysis of VENOST study. Seizure 2020;78:113117.

26. Yablon SA. Posttraumatic seizures. Arch Phys Med Rehabil 1993;74:9831001 .

27. Prince DA, Parada I, Graber K. Traumatic brain injury and posttraumatic epilepsy. In: Noebels JL, Avoli M, Rogawski MA, Olsen RW, DelgadoEscueta AV (eds). Jasper's Basic Mechanisms of the Epilepsies. Bethesda, MD: National Center for Biotechnology Information; 2012. 